\title{
The ILO Work in Fishing Convention: Gap Analysis, and the Wellbeing of Malaysian Fishers
}

\author{
Mohd Fadzil Shuhaimi bin Ramli \\ Faculty of Science and Biotechnology, University of Selangor, Bestari Jaya, Selangor, MALAYSIA.
}

\begin{abstract}
In Malaysia, about 166,188 fishers (locals and foreigners) do not fully enjoy the protection and benefits that other segment of workers are getting although by law they are entitled to be treated as legitimate workers. The ILO Work in Fishing Convention (the Convention) and its accompanying Work in Fishing Recommendation is about providing fishers the right to have decent working condition on board of fishing vessels. Although Malaysia, a party to the Convention, does not rectify the Convention, some local laws are already in place to tackle the fisher's matters. The objective of this paper is thus to perform Gap Analysis (comparative analysis) which helps to determine whether the current local laws are consistent with the provisions contained in the Convention. It is found that in general, the existing local laws are adequate to ensure fishers receive reasonable attention from their employers; however it is up to the authority to enforce the laws.
\end{abstract}

Keywords: ILO Work in Fishing Convention, GAP analysis, fishers

\subsection{Fishing overview}

\section{Introduction}

There are 49,756 licensed vessels operating various fishing gear types of which 27,471 operating at the South China Sea and the remaining 22,285 at the Straits of Malacca [1]. The number of local fishers working in those vessels is 129,622 while in addition; there are 36,566 foreign fishers majority of them working in larger vessels. Fishers working on the licensed vessels are registered by the Department of Fisheries (DOF) after complying certain conditions as set up by the department, among other things, they must be full-time fishers and aged more than 18 years old (no age ceiling) [2]. According to the DOF's policy, a person is termed a fisher if he is a licensed boat owner or employed as a crew member of a licensed boat and concurrently being issued a fisher's identity card, whereas the Fisheries Association Act 1971 only admitting a person as member if he is spending 120 days or more in fishing activities per year [3].

Under the Fisheries Act 1985 (Act 1985), the zoning system has been set up to segregate the traditional and the commercial fishing. The sea area under the $5 \mathrm{~nm}$ or denoted as Zone A is strictly for traditional fishers operating gears such as gill-nets, traps, lift-nets, hooks and lines etc. The Zone B, is the waters between $5 \mathrm{~nm}$ and $12 \mathrm{~nm}$ strictly for commercial gears (trawler and purse-seiner) operated by vessels less than 40 GRT. The commercial fishing vessels larger than 40 GRT but less than 70 GRT are confined in waters between $12 \mathrm{~nm}$ and $30 \mathrm{~nm}$ which are denoted as Zone C while any vessel above 70 GRT is categorized as engaging in deep-sea fishing in waters beyond $30 \mathrm{~nm}$ or the Zone $\mathrm{C} 2$. However, the regulation allows vessels to operate freely in waters beyond their assigned zone. For example, traditional fishing vessels are allowed to fish in all zones but for trawlers or purse-seiners under 40 GRT, they are prohibited to fish in Zone A only. Similarly, commercial vessels between 40 GRT and 70 GRT only to fish in Zone C and C2 while vessels above 70 GRT must fish in waters beyond $30 \mathrm{~nm}$. Another recent development in this respect is tuna fishing category whereby the vessels are to fish only in Indian Ocean (Zone D) regardless of the tonnage in concern.

Fishing vessels in Malaysia are measured or categorized according to their gross registered tonnage (GRT) and to certain extend, restriction on the engine's capacity (h.p.- horse-power).The GRT and hp is the indicator of fishing effort explaining their roles in resource management. It is found that the formula in obtaining the GRT is as follows; Length (L) X Breadth (B) X Depth (D) X 0.285.. The main reason of adopting weight rather than length as a measurement for fishing vessels is because of irregularity found in design and shapes of each vessel since most of them are traditionally built. It is then more appropriate and practical to adopt tonnage and the horse-power as measurement of fishing effort since length alone does not really reflect the strength of the vessel. However, by looking through data base kept at the DOF Headquarters in Putrajaya, only 298 vessels or $0.8 \%$ of the total number are found to be over $24 \mathrm{~m}$ in length.

Capture fisheries contribute about 1.4 million tons fish valued at RM 6.7 billion. in 2010 [1]. Since most of the waters in Malaysia are found to reach the optimum level of exploitation [4], fish landings over the past few years are almost constant in the regions of 1.3 million tons and 1.4 million tons. However, fish supply by capture fisheries is predicted not too last long, thus, the government has given great effort in developing tuna 
fishing in Indian Ocean and aquaculture to meet future demand. Presently, the production in aquaculture does not provide a relieve to the present demand of fish estimated about $56 \mathrm{~kg}$ per capita [5], thus, capture fisheries remains major contributor of fish for the nation.

\subsection{ILO Work in Fishing Convention 2007}

The ILO Work in Fishing Convention (the Convention) and its accompanying Work in Fishing Recommendation, which was adopted by an overwhelming majority at the 96th Session of the ILC in 2007, will come into force a year after 10 countries (including 8 coastal states) have rectified it [6]. The Convention is about providing fishers the right to have decent working condition on board of fishing vessels [7]. To date, Malaysia has not rectified the Convention [8].

\subsection{Relevant laws and regulations on wellbeing of fishers}

The main purpose of the Act 1985 is to protect fisheries resources by implementing appropriate resource management plan [9]. Although, the wellbeing of the fishers has not been appropriately addressed, there are few provisions that allow the authority to impose regulations such as in manning of the vessels (section 61 (c)) and vessel design and built (Section 9) that may improve the living condition of the fishers.

With regard to the wellbeing of workers, particularly in safety and health at work, the Occupational Safety and Health Act 1994 (OSH Act) was enacted and enforced by Department of Occupational Safety and Health (DOSH) under the Ministry of Human Resource. Section 1 (2) of the OSH Act states that it applies to all Malaysian industries as specified in the First Schedule (fishing is one of the industries specified in the First Schedule), however the OSH Act exempts work on board ships governed by the Merchant Shipping Ordinance 1952 (MSO) [10]. Then, work on fishing vessels below 500 GRT comes under the purview of the OSH Act since they do not fall under the jurisdiction of the MSO [11]. In addition, the DOSH issued the guidelines on occupational safety and health in fishing operation of which some provisions are mandatory since they are consistent with the OSH Act. Where the word 'must' is used, it means that section of the guidelines is contained within the OSH Act and is a legal requirement.

Other laws that are related to work in fishing are the Employment Act 1955, Workmen's Compensation Act 1952, Wages Councils Act 1947, Weekly Holidays Act 1950, Workers' Minimum Standards for Housing and Amenities Act 1990, Children and Young Persons (Employment) Act 1966, Private Employment Agencies 1981, and Employment Information Act 1953.

\section{Methodology}

In the next part of this paper, where GAP analysis is concerned, the provisions of all relevant laws already existing in Malaysia were analyzed to determine whether they are consistent with the whole issue of the betterment of the welfare of the fishers. The method used follows the ILO's guideline to undertake a comparative analysis of the Work in Fishing Convention, 2007 and national laws, regulations or other measures [12].However, only important provisions of the Convention are highlighted in this paper that may have significant impact on the fishers in general.

\subsection{Gap Analysis}

\section{Results and discussion}

The Convention is divided in nine parts (Part I through Part IX) with 54 articles. Only articles that have significant impact on fishers are selected and two parts of the Convention; Part VIII (Amendments of Annexes I, II, and III) and part IX (Final Provisions) are not covered in this analysis.

\subsubsection{Part 1 Definition}

Commercial fishing

Convention: Article 1 (a) stipulates that all fishing operations including those operated in rivers, lakes or canals are defined as "commercial fishing" but do not include subsistence fishing and recreational fishing. Generally, the Convention applies to all fishers and vessels engaged in commercial fishing (Article 2 [1]). The competent authority, however, has the power to determine whether a particular fisher or vessel is engaged in commercial fishing or otherwise (Article 2 [2]). Article 3 allows members to exempt fishing operations in rivers, lakes or canals and limited categories of fishers or fishing vessels from the requirement of the Convention where its application raises special problems of a substantial nature. Reading in tandem article 1 (a) and article 2 (2) and considering article 3 , the competent authority is delegated to determine or specify local fishing operations into three categories; commercial fishing, subsistence fishing and recreational fishing

Act 1985: In Malaysia, as typically adopted by DOF, traditional fishers are those operating fishing appliances/gears with un-motorized vessel or motorized vessel less than 40 GRT as stipulated under Section 2 of 
the Act 1985. Customarily, the words artisanal, small-scale and traditional fishing have been used interchangeably referring the act of operating traditional fishing appliances. However, the phrase 'subsistence fishing is seldom used. As defined by FAO, subsistence fisheries is where the fish caught are shared and consumed directly by the families and kins of the fishers rather than being bought by middle-(wo)men and sold at the next larger market [12]. This explains why it is seldom used since it is rare for the fishers not to sell a portion of his catches to someone else.

On the other hand, commercial fishers are those using fishing appliances other than the stipulated traditional appliances. The New Licensing Policy of DOF designates trawlers and purse-seiners as commercial gears (with the exception of anchovies purse-seiners). The commercial fishers are not allowed to operate in waters less than $5 \mathrm{~nm}$ from the coast-line.

Recreational fishing regulation is underway, but following FAO, it is defined as harvesting fish for personal use, fun, and challenge (e.g. as opposed to profit or research) [13]. Recreational fishing does not include sale, barter or trade of all or part of the catch. In Malaysia, recreational fishing means using rod and line with no more than one hook.

\section{Fishers}

Convention: Article 1 (e) define "fishers" as those working on board fishing vessels excluding pilots, naval personnel, government officers, shore-based persons carrying out work on board a fishing vessel and fisheries observers.

Act 1985: Fishers are not defined but, Section 8 of the Act stated the need of any person operating local fishing vessels for the purpose of fishing to have a valid license and "person' is defined as any individual (whether or not a citizen of Malaysia), anybody corporate, partnership, association, or other entity, established within or outside Malaysia, the federal or any other State Government, a local authority or foreign government, or any entity belonging thereto (Section 2). However, the practice is that only the vessel owner (the employer) is to obtain the license while any other person on board the vessel is considered as a crew (employee) of that particular vessel. If the owner is non-operator, then the appointed person to head and man the vessel by the owner is the skipper of the vessel.

\section{Length and Length Overall}

Convention: Article 1 (i) and (j) specifies how vessels are measured. Referring to Annex I pertaining to equivalence in measurement, inter alia, the LOA of 26.5 metres is to be considered equivalent to a length of 24 metres as adopted by the Convention.

Act 1985: the practice under the Act 1985 is to adopt the LOA measurement, i.e., the distance in a straight line parallel to the designed waterline between the foremost point of the bow and the aftermost point of the stern (similar to Article 1 (j) of the Convention).

Hence, converting these measurements from the LOA to length (L), about 58 out of 298 vessels are ineligible to be in the $24 \mathrm{~m}$ and above category.

\subsubsection{Part II General Principles}

Convention: Article 8 states the responsibilities of vessel owners, skippers and fishers.

Act 1985: Section 8 (b) and (c) requires any person operating a vessel for the purpose of fishing to obey any condition as specified in the license or any other direction in writing issued by the authority.

OSH Act 1994: Section 15 (1) stipulates that it is the duty of every employer and every self-employed person to ensure, so far as is practicable, the safety, health and welfare at work of all his employees.

\subsubsection{Part III Minimum Requirements for Work On Board fishing vessels.}

\section{Minimum Age}

Convention: Article 9 stated that the minimum age for work on board a fishing vessel is 16 year but if the activities on board the vessel might jeopardize the health, safety or morals of young persons, then the minimum age will be 18 years. Person of 15 years or less could be employed subject to conditions imposed by the competent authority. 
Act 1985: The minimum age is not stated in the Act. However, under the license conditions as stipulated by the Director-general of Fisheries, the minimum age for the vessel owner (the licensee) should be no less than 18 years. Similarly, those fishers registered with the DOF should be at the age of 18 years and above.

Children and Young Person (Employment) Act 1966: The purpose of this act is to protect children and young person from being unfairly exploited and jeopardizing their education.

Children of age less than 14 years are allowed to work only between 7 a.m. and 8 p.m., not more than 6 hours per day or if still schooling, the total hours between schooling and work should not more than 7 hours. They should be allowed to rest no less than 30 minutes for every three hours work. The nature of work should be light, family business, public entertainment or as allowed by the government.

Children of age between 14-18 years are allowed to work only between 7 a.m. and 8 p.m., not more than 7 hours per day or if still schooling, the total hours between schooling and work should not more than 8 hours. They should be allowed to rest no less than 30 minutes for every four hours work. They begin work after a break of no less than 12 hours. The nature of work should be light, not necessary in family business, domestic servant or maid, in industries suitable with their competencies, and in any vessel owned by their parents.

\section{Medical Examination}

Convention: Article 10 (1) requiring all fishers to have a valid medical certificate attesting to fitness to perform their duties but in paragraph (2), allowing the competent authority to exempt such requirement after taking into account the safety and health of fishers, size of the vessel, availability of medical assistance and evacuation, duration of the voyage, area of operation, and type of fishing operation. This exemption, however, does not applicable to vessels of $24 \mathrm{~m}$ length or above or that normally remain at sea for more than three days. Medical certificate for fisher working on board fishing vessel of 24 meter and over or remain at sea more than three days is compulsory (Article 10[3]) and additional health check-up requirements are imposed (Article 12).

OSH Act 1994: There is a general responsibility of the employer relating to safety, health and welfare at work as stated in Section 15 (1). If the organization employed 40 or more persons, then such organization is to establish a safety and health committee (Section 30 (1)(a))

\subsubsection{Part IV Condition of Service}

\section{Manning and Hours of Rest}

Convention: Article 13 requires each member to ensure that fishing vessels are sufficiently and safely manned for the safe navigation and operation of the vessel and under the control of a competent skipper. Fishers are given regular periods of rest of sufficient length to ensure safety and health. For vessels of $24 \mathrm{~m}$ in length and over, there must be a minimum level of manning for the safe navigation of the vessel, specifying the number and the qualifications of the fishers (Article 14 (1)(a)). With regard to rest hours, any vessel remaining at sea for more than three days, fishers are entitled to have rest not less than ten hours in any 24-hour period; and 77 hours in any seven-day period (Article 14 (1) (b)).

Act 1985: Annual renewal of the fishing licenses includes inspection of the vessels by the licensing officer to ensure the seaworthiness of the vessel and all crew members to produce life insurance and valid membership of the Fisherman Association (Section 10). This licensing procedure, inter alia, is to ensure the vessels will be manned by appropriate individuals possessing the very minimum qualification such as able to comprehend regulations as set by the Act 1985. There is no provision pertaining to rest hour in the Act 1985 .

When the need arise, the Act 1985 is capable of enacting regulation pertaining to manning as laid by Section 61 (c) that stipulates the power of Minister to make regulation, inter alia, to prescribe manning standards for fishing vessels.

Employment Act 1955: According to this act, an employee shall not work on normal hours exceeding 8 hours a day excluding a period of rest which is one whole day in a week, five consecutive hours of work without a period of rest of not less than 30 minutes and 48 hours in a week.

Crew List

Convention: Article 15 requires crew list to be provided to the authorized person prior to departure of the vessel.

Act 1985: Under Section 10, the vessel owner is to submit a crew list for the annual renewal of his license. There is no such order for the vessel owner to submit the crew list prior to departure of the vessel. 
Fisher's Work Agreement

Convention: Article 16 through Article 20 require work agreement to be made between fisher and vessel owner of which a copy is given to the fisher and made accessible on board the vessel. A vessel owner who singlehandedly operating the vessel is exempted (Article 19).

Employment Act 1955: Under this act, a written contract of employment must be given to every employee where the employment period exceeds 1 month. The contract must include particulars of the terms and conditions of employment and notice period required to terminate it. A contract of service shall contain particulars of:

(i) the names of employer and employee

(ii) the date when the employment began

(iii) the place of work or an indication of that and of the address of the employer

(iv) the title of the job which the employee is employed to do or a brief description of the work for which a person is employed

(v) the commencement salary and where applicable other allowances and bonus

(vi) any terms and conditions relating to :

probation period,

hours of work,

entitlement to holidays, including public holidays,

overtime pay and leave in lieu ,

incapacity for work due to sickness or injury, including any provision for sick pay and medical bills,

EPF and SOCSO schemes,

the length of notice which the employee is obliged to give and entitled to receive to terminate the contract of service or a clause on the manner in which the contract of service may be terminated.

Payment of Fishers

Convention: Article 23 requires fishers to be paid a monthly wage or other regular payment and they should be given a mean to transmit all or part of their payment to their families at no cost (Article 24).

Employment Act 1955: According to this act, wages earned must be paid not later than the 7th day after the last day of any wage period. An employee has the right to be given by an employer, at or before the time at which any payment of wages or salary is made to such employee, a written itemized pay statement.

\subsubsection{Part V Accommodation and Food}

Convention: Article 25 through 27 stipulates the need to improve the standard of accommodation and food served on board the vessel. In Article 28, special reference is given to Annex III concerning vessel accommodation.

Act 1985: None. However, Section 10 allows the Director-General to formulate conditions, as he thinks fit, for proper management of fisheries. As such, he may specify vessel designs and built in accordance to the Convention requirement. In Malaysia, since time immemorial, it is customary for the vessel owner to provide food for the crews and a decent space for accommodation, though, it might not up to the standard as expected internationally.

\subsubsection{Part VI Medical Care, health Protection and Social Security}

Medical Care

Convention: It requires vessel to carry appropriate medical equipment and medical supplies with at least one fisher on board trained in first aid or other form of medical care.

\section{Social Security}

Convention: Article 34 through Article 37 stipulates the need for fishers and their dependants to enjoy the social security benefits.

Employment Act 1955: An employee employed under a contract of service or apprenticeship and earning a monthly wages of RM2,000 and below must compulsorily register and contribute to Social Security 
Organization (SOCSO) regardless of the employment status whether it is permanent, temporary or casual in nature. The SOCSO provides social security protection by social insurance including medical and cash benefits, provision of artificial aids and rehabilitation to employees to reduce the sufferings and to provide financial guarantees and protection to the family.

Protection In the Case of Work-Related Sickness, Injury or Death

Convention: Article 38 and Article 39 stipulate that fishers to receive medical care, compensation, insurance or other schemes as protection against injury, death or sickness.

Fisheries Act 1985: Personal insurance (against death) is compulsory for each crew of the fishing vessel (Section 10, licensing condition)

\subsubsection{Part VII Compliance and Enforcement}

Convention : Article 40 through Article 44 stipulate the need to enforce the requirement of the Convention in order to ensure compliance.

Act 1985: Section 25 (b) of the Act states that failure to comply with any provision of the Act 1985 is guilty of an offence and the person is liable to a fine not exceeding RM 20,000 or a term of imprisonment not exceeding two years of both. Penalty stated in Section 25 (a) relates to foreign fishing vessels and foreign fishers and only confined to fishing offences.

\subsection{Flexibility of the Convention}

\section{Conclusion}

In general, the Convention is supposedly does not giving significant impact to the present or at least in the next 10 years nation's fishing industry particularly in capture fisheries as it provides so much flexibilities for the members to decide or define some provisions to be imposed. The flexibilities contained in the Convention are as follows:

1. Article 1 (a) stipulates that all fishing operations including those operated in rivers, lakes or canals are defined as "commercial fishing" but do not include subsistence fishing and recreational fishing. Generally, the Convention applies to all fishers and vessels engaged in commercial fishing (Article 2 [1]). The competent authority, however, has the power to determine whether a particular fisher or vessel is engaged in commercial fishing or otherwise (Article 2 [2]). Reading in tandem article 1 (a) and article 2 (2), the competent authority is delegated to determine or specify local fishing operations into three categories; commercial fishing, subsistence fishing and recreational fishing.

2. Article 3 allows members to exempt fishing operations in rivers, lakes or canals and limited categories of fishers or fishing vessels from the requirement of the Convention where its application raises special problems of a substantial nature.

3. Article 4 allows progressive implementation of all or some of the provisions stipulated under the Articles 10 (1) and (3), 15, 20, 33 and 38 for reason of insufficient developed infrastructure or institutions (However, it does not provide similar exclusion to vessel of 24 meters or more, or remain at sea more than seven days, or navigate at a distance exceeding 200 nautical miles etc).

4. Article 5 allows members to use either length (or length overall) for the purpose of the Convention or gross tonnage in place of length (or length overall) for the purpose set in Annex III, as the basis for the measurement of the vessels.

5. A stern requirement for each fisher to acquire medical certificate is set by Article 10 (1) of the Convention, but, sub-article 2 allows members to decide for the exemptions of this requirement in light of the importance of fishers safety and health, and after considering the size of the vessel, availability of medical assistance and evacuation, duration of the voyage, area of operation, and type of fishing operation.

6. With regard to the fisher's work agreement as stipulated by Article 16 through Article 20 of the Convention, an exemption is given to vessel owner who single-handedly operating the vessel. 


\subsection{Specific Requirements for Vessel of 24 Meters and Over}

Since Malaysian fishing vessels are generally small, very few over 24 meters in length, the immediate effect or impact of the Convention to the development of fishing industry is minimal. However, with the encouragement and development of tuna fishing particularly in Indian Ocean, in the few years' time, there will be more vessels of 24 meters or over. Vessel owners should be alerted about the Convention requirement on the accommodation of fishers (Annex III) particularly for the new vessels. This can be done through the approval of the licenses by the DOF. Other provisions that perhaps should be of importance for the future 24 meters and over-vessel-owners are as follows:

1. Medical certificate for fisher working on board fishing vessel of 24 meter and over is compulsory (Article $10[3])$.

2. Additional health check-up requirements are imposed (Article 12).

3. As stipulated by Article 14(a), the competent authority should establish the minimum level of manning, specifying the number and qualifications of the fishers required for fishing vessels 24 meters and over.

4. Additional medical care requirements as set by Article 30.

5. Article 32, with respect to occupational, safety and health and accident prevention, specifically imposed upon fishing vessels of 24 meters and over.

6. The need to carry a valid document stating the vessel has been inspected and endorsed by the competent authority to comply with the requirement of the Convention concerning living and working conditions (Article $41)$.

\section{Acknowledgment}

The author wishes to thank the University of Selangor in general and the Dean of Faculty of Science and Biotechnology in particular for encouragement and assistance given during the preparation of this paper.

\section{References}

[1] Annual Fisheries Statistics 2010 (n.d.). Department of FisheriesMalaysia. Oct26,2012, from

http://www.dof.gov.my/perangkaan2010

[2] Fisheries Act 1985. Act 317. Section 11(1) (1996). Retrieved from

http://www.dof.gov.my/html/themes/moa_dof/documents/Fisheries_Act_1985_BI_English_Akta_Perikanan_1985.pdf

[3] Fisheries Association Act 1971. Act 44. Section 11 (1) (a) (2006). Retrieved

fromhttp://www.lkim.gov.my/html/themes/moa_lkm/images/moa_lkm/new/content/akta_44_Persatuan_Nelayan.pdf

[4] Stobutzki, I.C. et al (2006) "Decline of demersal coastal fisheries resources in three developing Asean countries, Fisheries Research, Vol. 78, Issue 2-3, May 2006, pp 130-142

[5] Ahmad, A; Mohamed, Z and Ismail, M (2011) "Determinants of fresh fish purchasing behaviour among Malaysian consumers", Current Research Journal of Social Sciences, Vol. 3 (2), pp 126-131

[6] International Labour Organisation (2011) Work in fishing convention and recommendation- Action plan 2011-2016.Retrieved from http://www.ilo.org/wcmsp5/groups/public/@ed dialogue/@sector/documents/publication/wcms 161220.pdf

[7] Food, Agriculture and Decent Work (2012) Fisheries. Retrieved from http://www.fao-ilo.org/agricultural-sectors/fao-ilofisheries/en/

[8] International Labour Organisation (1996-2012) Up-to-date conventions not rectified by Malaysia. Retrieved from http://www.ilo.org/dyn/normlex/en/f?p=1000:11210:0::NO::P11210_COUNTRY_ID:102960

[9] Fisheries Act 1985. Act 317. Part III (1996).Retrieved from

http://www.dof.gov.my/html/themes/moa_dof/documents/Fisheries_Act_1985_BI_English_Akta_Perikanan_1985.pdf

[10] Occupational Safety and Health Act 1994. Act 514. Section 1 (3).(n.d.). Retrieved from

http://www.dosh.gov.my/doshv2/index.php?option=com_phocadownload\&view=category\&id=2\&Itemid=98\&lang=en

[11] Merchant Shipping Ordinance 1952. Section 13 (2010). Retrieved from http://www.marine.gov.my/law/merchant\%20 shipping\%20ordinance.pdf

[12] International Labour Organisation (n.d.). Guideline for an approach to undertaking a comparative analysis (or "gap analysis") of the Work in Fishing Convention, 2007 (No. 188) and national laws, regulations or other measures concerning decent conditions of work on board fishing vessels with regard to minimum requirements for work on board; conditions of service; accommodation and food; occupational safety and health protection; medical care and social security. Retrieved from

http://www.ilo.org/wcmsp5/groups/public/@ed_dialogue/@sector/documents/publication/wcms_161223.pdf

[13] International Labour Organisation (2012.).Recreational fisheries. Retrieved from http://www.fao.org/fishery/topic/14831/en 